DOI: 10.26693/jmbs04.05.332

UDC $613.96+314.172$

Kalynychenko D. 0.

\title{
SOCIAL-HYGIENIC ASPECTS OF REPRODUCTIVE BEHAVIOR AND REPRODUCTIVE SETTINGS OF GIRLS AGED 17-22
}

\author{
Sumy State Pedagogical University named after A. S. Makarenko, Ukraine
}

kalinichenko.dmitriy.mail@gmail.com

The article highlights and analyzes the peculiarities of reproductive behavior of girls of different age groups, defines factors that determine it.

The purpose of the article was to study the reproductive behavior of girls aged 17-22 and reproductive settings for use in developing regional demographic policies and monitoring demographic situations.

The survey involved 284 students of higher education institutions. The results of the anonymous questionnaire were analyzed in two age groups: 1719 years old - I group (145 persons) and 20-22 years old - II group (139 persons).

We used a specially designed anonymous questionnaire, which addressed the issues of reproductive settings, levels of awareness and sources of information about sexual education, beginning of sexual life, use of contraceptives, HIV status.

According to medical examinations, $76.92 \%$ of girls were recognized as healthy, and $23.08 \%$ of the examined had chronic reproductive diseases. The debut of sexual activity falls mostly on the age range of 17-18 years old (34.57\%) and $15-16$ years old $(19.15 \%)$. In $5.53 \%$ of students, sexual intercourse was accompanied by pregnancy, followed by its interruption. The main source of information on reproductive behavior and reproductive health in the youth environment are peers and friends (48.40\%), medical internet resources $(45.74 \%)$, interviews with parents $(32.45 \%)$, mass media and advertising $(28.72 \%)$, thematic classes in education institutions (17.02\%). According to the survey, $31.71 \%$ of students, who had in the anamnesis accidental sexual intercourse, had diseases of the reproductive system. The study found out that $73.31 \%$ of respondents considered two children the ideal number of children in the family, $16.17 \%$ of girls gave preference to three children in the family, and $7.89 \%$ of girls wanted only one child. Childfree is considered to be an «ideal» option by $2.26 \%$ of students. Taking into account the required quality of life, $70.40 \%$ of the respondents would like to have two children in the family, $11.55 \%$ and $12.27 \%$ would like to have one and three children, respectively. Under these conditions, $4.33 \%$ of girls would not like to have any children at all. However, at the time of the survey, only $49.82 \%$ of girls would like to have two children, $5.05 \%$ of students dreamt to have three children, and $19.86 \%$ - one child and $25.27 \%$ did not plan to have children. However, at the time of the survey, only $49.82 \%$ of girls would like to have two children, $5.05 \%$ of girls - threechildren, $19.86 \%$ - one child and $25.27 \%$ - do not plan to have children at all.

The study of reproductive behavior and reproductive settings is important for understanding and predicting birth rates in the region, for developing concrete measures for effective demographic and family policies

Keywords: reproductive behaviour, reproductive settings, reproductive health, girls.

Research relation to the plans, programs and research themes. The article is a fragment of the Scientific Research Project of Chair of Medical and Biological Foundations of Physical Culture of the Educational and Scientific Institute of Physical Culture «Assessment of Reproductive Health of Adolescents and Youth with Different Types of Gender Identity», State Registration Number 046 U007542 (09.2016 12.2020).

Introduction. Recently, in Ukraine there has been a rather unfavorable medical-demographic situation characterized by unsatisfactory state of health of the population, low fertility rate in combination with high mortality rate, negative natural population growth, and also high prevalence of chronic non-infectious diseases $[1,2]$. In these conditions reproductive potential of the population, especially youth, the age of active reproduction gains a special significance.

It is well-known that fertility is a result of reproductive behavior of people who differently assess the degree of significance for them of socio-economic conditions of life and make an appropriate decision on the birth of children.

Reproductive health is influenced greatly in adolescence and early fertility age, because in this period there occurs an intensive development at the somatic level and socialization of the individual with formation of all systems of the organism, including reproductive system, cognitive, emotional and value spheres, and a 
versatile personality. In this age on the background of various factors of the environment the bases of a healthy lifestyle, elements of reproductive behavior, attitude to marital relations are laid and formed, and harmful habits appear [2].

According to $\mathrm{WHO}$, through elimination of five global health-related factors, including risky reproductive behavior, we can prevent HIV/AIDS, sexually transmitted infections, which can cause infertility, complications of pregnancy and childbirth, problems in sexual and family relationships [2, 3]. About two thirds of cases of premature death and one third of the total number of adult diseases are due to conditions and forms of behavior in adolescence, including smoking, lack of physical activity, unprotected sex and violence $[4,5]$.

Strategies and approaches to strengthening the policy of the countries of the European region on population and development are also identified in the WHO European Action Plan on Strengthening Protection of Sexual, Reproductive Health and Rights for 2017-2021. Here are the main problems in reproductive health of the population of Ukraine: increasing depopulation processes; lack of policies and a sustainable system for educating children about sexual and reproductive health [6, 7].

Self-reproduction of the population is a property of social life, which is considered to be a system with a demographic concept. In turn, the demographic process is a category that reflects the quality of the system of social life and its ability to perform a demo-creative function [4, p. 114].

The reproductive health $(\mathrm{RH})$ is an integral part of general health of the population and, according to the International Conference on Population and Development (Cairo, 1994), «is not merely an indication of the absence of diseases of the reproductive system or of violations of its functions, but a state of complete physical, mental and social well-being, envisaging the possibility of satisfactory and safe sexual life, ability to reproduce, the right of men and women to information and access to safe and effective methods of planning the family and other methods of birth control». According to many researchers, it is not correct to use the term «reproductive health» to describe unfavorable trends, which characterize health of the population and more appropriate in this case, especially for young people, is to use the term «reproductive potential» (Yuriev V. K., 2000; Ivanov A. G., 2005; Surmach M. Yu., 2007). A significant constituent of the concept of «reproductive potential» is reproductive behavior (RB). According to sociologists, RB is the result of assimilation of reproductive norms, inherited from the reproductive experience of previous generations. In turn, reproductive norms are principles and patterns of behavior associated with the birth of a certain number of children and adopted in various social groups [8]. Unfortunately, under current conditions, the RB is formed on the background of an inadequate level of general and reproductive culture of the population, democratization of sexual relations, high level of artificial abortion, lack of awareness on the issues of preservation of reproductive health, destruction of family values.

Therefore, today public health-saving strategy [9] is a priority, and it involves development and implementation of cross-sector measures aimed at promoting healthy lifestyles, responsible parenting and safe motherhood.

The aim of research was to study the reproductive behavior of girls aged 17-22 and reproductive settings for use in developing regional demographic policies and monitoring demographic situations.

Materials and methods of research. The survey involved 284 students of higher education institutions of Sumy, who were not married. The results of the anonymous questionnaire were analyzed in two age groups: 17-19 years old - I group (145 persons) and 20-22 years old - II group (139 persons).

The study was carried out in compliance with the principles of voluntariness, with the guarantee of protection of human rights and freedoms, inviolability of physical and mental integrity, respect for the principles of justice and equity in accordance with the "Helsinki Declaration of the World Medical Association» (2005). In order to receive the initial information, together with the Youth-Friendly Clinics in Sumy, a special anonymous questionnaire was developed, the questions of which covered the leading factors in the formation of reproductive behavior of youth. In addition, reproductive settings were studied according to generally accepted indicators (the first two positions are the theoretical model of the family composition): 1) «ideal» number of children - the number of children that a family should have, the so-called social «norm of the $R B$ »; 2) «desirable» number of children - the number of children which at the time of the study wants to have a respondent provided that all favorable living conditions are available; 3) «expected» (planned) number of children - indicates actual planning of the composition of the family taking into account current situation of life.

Comparison of groups by qualitative features was performed using Pearson's $x 2$ criterion. Differences were considered statistically significant at $p \leq 0.05$.

Research results and their discussion. In the course of the study it was found out that subjective evaluation of reproductive health tends to be underestimated. In particular, $30.61 \%$ of students consider themselves healthy. At the same time, according to 
targeted medical examinations, $76.92 \%$ of girls were recognized as healthy, and $23.08 \%$ of the examined had chronic reproductive diseases. Established contradiction, probably, can be explained by functional disorders on the part of $\mathrm{RH}$ (premenstrual syndrome, functional impairment of MC, etc.), which in $55.10 \%$ of students allowed to evaluate $\mathrm{RH}$ as «I have minor violations». According to the medical survey, there is a tendency to increase the number of chronic diseases of the reproductive system in students with age (22.29\% - in group I and $24.32 \%$ - in group II). We used data on sexual activity in the youth environment for the characteristics of the RB. The obtained results showed that $66.37 \%$ of girls had sexual relationships $(57.80 \%$ in group I and $81.55 \%$ in group II $\left.\left(X^{2}=16.38 ; p<0,001\right)\right)$. These data coincide with allUkrainian indicators of previous studies [2, p. 109].

The debut of sexual activity falls mostly on the age range of $17-18$ years old (34.57\%) and 15-16 years old (19.15\%) with a minimum specific weight of the groups «19-20 years old» $(7.68 \%)$, «13-14 years old» $(2.13 \%)$, «after 20 years old» $(1.60 \%)$ and «under 13 years old» $(0.53 \%)$. At the same time, only $3.76 \%$ of the respondents regreted the early beginning of sexual activity. In $5.53 \%$ of students, sexual intercourse was accompanied by pregnancy, followed by its interruption. In $38.83 \%$ of students who had sexual experience, there was a relationship with one partner, $21.28 \%$ of girls had two-five partners, $4.26 \%$ - more than five partners. Unfortunately, $13.83 \%$ of the respondents did not disregard casual sexual intercourse, and this category of girls dominated in the II age group (22.95\%) compared with the I age group (9.45\%) ( $\left.x^{2}=20.89 ; p<0,001\right)$. In $58.12 \%$ of students, a significant cause of the first sexual debut was love and curiosity $(9.75 \%)$, a minor contribution to the I and II age groups had occasional sexual intercourse caused by alcoholic intoxication $(6.56 \%$ and $3.94 \%$ respectively), perseverance of the partner (2.30\% and $1.81 \%$ respectively). With age, the importance of feeling to the opposite sex for girls in relationships is increasing, which indicates the fact that girls aged $20-22$ give preference to love in sexual intercourse $(70.87 \%)$, compared to the group of $17-19$ year-old students $(50.57 \%),(x 2=10.95 ; p<0.001)$. The established peculiarities can be explained by greater responsibility and awareness of their reproductive behavior that occurs with age in the process of socialization of the individual. In order to substantiate negative influence on $\mathrm{RH}$ of early and disorderly sexual behavior, the pathological deficiency of girls in diseases of the reproductive system was analyzed, depending on the number of sexual partners. According to the survey, $31.71 \%$ of students who had in the anamnesis accidental sexual intercourse, got dis- eases of the reproductive system; with a number of sexual partners from 2 to 5 , the group of dispensary observation constituted $25.15 \%$ of the polled, with one $-18.92 \%$ of students. When comparing the groups of girls according to the criterion of the presence/absence of sexual intercourse, no probable differences in the characteristics of MC were found, but a smaller number of girls with normal duration and minor bleeding in a group of sexually active students were found, compared with a group of girls who had no sexual partners in the anamnesis $(63.86 \%$ and $65.38 \%$ respectively). Girls who live a sexual life have a longer duration of the menstrual phase (15.66\%), increased blood loss (10.84\%), compared with another group (11.54\% and $7.69 \%$, respectively).

Contraception, as a method of family planning, can simultaneously be considered a way to prevent abortion and complications associated with it. The assessment of students' awareness of contraceptives indicates that $43.62 \%$ of the respondents in the group of sexually active students constantly use them, $17.55 \%$ - sometimes, and $2.66 \%$ of students have never used. To the question «Do you know your HIV status?» $38.83 \%$ of the respondents answered yes, $49.47 \%$ did not have such information, and $11.70 \%$ of the polled did not consider it necessary to be examined for HIV.

The problem of unwanted pregnancy and high risk of STI/HIV infection is closely linked to issues of sexual, hygienic and moral education in the family and the level of knowledge on reproductive health, STI prevention and abortion. The main source of information on reproductive behavior and reproductive health in the youth environment are peers and friends (48.40\%), medical internet resources $(45.74 \%)$, interviews with parents $(32.45 \%)$, mass media and advertising $(28.72 \%)$, thematic classes in education institutions $(17.02 \%)$. At the same time, $89.36 \%$ of the girls consider themselves fully aware of the issues raised. In our opinion, students considerably overestimate their own volume of special information; in particular, girls from 17 to 19 years old consider themselves more aware $(90.55 \%)$ than girls from 20 to 22 years old $(86.89 \%)$. However, the need for information still exists; confirmation of this is the need to obtain additional information on sexual education and reproductive function for $53.78 \%$ of respondents in the form of lectures $(30.32 \%)$, trainings $(11.17 \%)$, booklets and literature (10.64\%).

Not only RB but also reproductive setting has impact on the reproductive potential of young people. Reproductive setting is a social setting, it affects reproductive behavior. Despite the fact that reproductive settings are viewed as one of the components of the phenomenon of parenting, nowadays, the process of 
their formation and development has not yet been studied [10]. Quantitative aspects of the reproductive setting are expressed in the orientation on a definite number of children. The study has found out that $73.31 \%$ of respondents consider two children the ideal number of children in the family, give preference to three children in the family $16.17 \%$ of girls, and one child $-7.89 \%$ of girls. Childfree is considered to be an "ideal" option by $2.26 \%$ of students. Provided the required quality of life, $70.40 \%$ of the respondents would like to have two children in the family, one and three children $-11.55 \%$ and $12.27 \%$ of students, respectively. Under these conditions, $4.33 \%$ of girls would not want to have a child at all. However, at the time of the survey, only $49.82 \%$ of girls would like to have two children, $5.05 \%$ - wanted to have three children, $19.86 \%$ of respondents wanted to have one child and $25.27 \%$ - did not plan to have children at all. At present, an impediment to implementation of the reproductive functions is low material wealth (63.54\%), health problems $(49.82 \%)$, no family $(21.30 \%)$, and unwillingness to change one's social status and leave the comfort zone (11.91\%).

Conclusions. The study showed that $23.08 \%$ of students had chronic diseases of the reproductive system, which was a risk group for the successful implementation of reproductive function.
The transformation of sexual behavior of young people consists in the cases of early onset of sexual activity, free attitude to marriage, early unwanted pregnancy, which is often interrupted, a significant number of sexual partners, and occasional sexual relationships. Contraceptives as prevention of unwanted pregnancy, sexually transmitted infections are constantly used by $43.62 \%$ of the respondents in the group of sexually active students, $17.55 \%$ - sometimes, and $2.66 \%$ of students have never used.

The problem of reproductive culture is also important, as well as its components: reproductive health, reproductive behavior and reproductive settings.

Reproductive settings of modern youth are mostly positive $(73.31 \%)$, but at the time of the survey, only $49.82 \%$ of girls would like to have two children, $5.05 \%$ - three, $19.86 \%$ - one child and $25.27 \%$ do not plan to have children. Negative development of reproductive settings occurs due to the economic status, lack of necessary living conditions, permanent partner (family), health condition.

Prospects for further research. The study of reproductive behavior and reproductive settings is important for understanding and predicting birth rates in the region, for developing concrete measures for effective demographic and family policies.

\section{References}

1. The Concept of the National Program «Health - 2020: Ukrainian Dimension» [digital resource]. Available from: http:// www.kmu.gov.ua/control/uk/cardnpd?docid=244717787

2. Yakymenko I, Tsybulin O, Shapovalov Ye. Healthy lifestyle behaviors among university students in Ukraine. Environment and health. 2017; 1(81): 41-5. https://doi.org/10.32402/dovkil2017.01.041

3. Global health risks: mortality and burden of disease attributable to selected major risks. Geneva: World Health Organization; 2009. 62 p.

4. Gender portrait of Ukrainian society. Analytical research. Ed by N Svitailo, V Pavlenko, A Kostenko. Sumy: Sumy SPU named after AS Makarenko; 2009. p. 114.

5. Loef $\mathrm{M}$, Walach $\mathrm{H}$. The combined effects of healthy lifestyle behaviors on all cause mortality: a systematic review and meta-analysis. Preventive medicine. 2012; 55(3): 163-70. PMID: 22735042. https://doi.org/10.1016/ j.ypmed.2012.06.017

6. The Concept of the National Program «Reproductive and Sexual Health of the Nation for the Period till 2021» [digital resource]. Available from: http://www.moz.gov.ua/ua/print/Pro_20170316_0.html

7. Balakirev OM, Bondar TV, Artiukh OR. The state and factors of health of Ukrainian teenagers. K: UNICEF, Ukr in-te of social research named after O Yaremenko. K: «K.I.S.»; 2011. 172 p.

8. Kozak Kh. Reproductive strategies of modern married couples. Humanitarian and social sciences: materials of the II International Conference of Young Scientists HSS-2011, 2011 November 24-26, Lviv, Ukraine. National University "Lviv Polytechnic». Lviv: Lviv Polytechnic Publishing House; 2011: 316-7.

9. Polka NS, Berdnyk OV. Modern approaches to the assessment of the state of health in childhood hygiene. Journal of the National Academy of Medical Sciences of Ukraine. 2013; 19(2): 226-35.

10. Kocharian OS, Svynarenko YuV. Psychological aspects of the concept of reproductive setting and its understanding in foreign studies. Bulletin of Kharkiv National University named after VN Karazin. Series «Psychology». 2014; 1121: 124-7. 
Удк $613.96+314.172$

СОЦІАЛЬНО-ГІГІЄНІЧНІ АСПЕКТИ РЕПРОДУКТИВНОЇ ПОВЕДІНКИ

ТА РЕПРОДУКТИВНИХ УСТАНОВОК ДІВЧАТ 17-22 РОКІВ

Калиниченко Д. О.

Резюме. У статті висвітлено та проаналізовано особливості репродуктивної поведінки дівчат різних вікових груп, визначено чинники, що ії детермінують.

Метою статmі було вивчити репродуктивну поведінку дівчат 17-22 років та репродуктивні установки для використання під час розробки регіональних програм демографічної політики та проведення моніторингу демографічної ситуації.

Дослідженням було охоплено 284 студентки вищих навчальних закладів. Результати анонімного анкетування аналізувалися у двох вікових групах 17-19 років - I група (145 осіб) та 20-22 роки - II група (139 осіб). Використовувалася спеціально розроблена анкета для анонімного опитування, питання якої стосувалися репродуктивних установок, рівня та джерел інфрормованості щодо статевого виховання, початку статевого життя, використання засобів контрацепції, інформованості про власний ВІЛ-статус.

Результати дослідження. За даними медичних оглядів 76,92\% дівчат визнані здоровими, 23,08\% оглянутих мають хронічні захворювання репродуктивної системи. Дебют сексуальної активності припадає максимально на віковий діапазон 17-18 років (34,57\%) і 15-16 років (19,15\%). У 5,53\% студенток статеві зв'язки супроводжувалися вагітністю з подальшим її перериванням. За даними опитування у 31,71\% студенток, які мали в анамнезі випадкові статеві зв'язки, виявлені хвороби репродуктивної системи. Основним джерелом інформації стосовно репродуктивної поведінки, репродуктивного здоров'я у молодіжному середовищі є однолітки та друзі (48,40\%), медичні інтернет-ресурси (45,74\%), бесіди з батьками (32,45\%), 3MI та реклама (28,72\%), тематичні заняття у закладах освіти (17,02\%). У ході дослідження установлено, що 73,31\% респонденток вважає дві дитини - ідеальною кількістю дітей у сім'ї, перевагу надають трьом дітям у сім"ї 16,17\% дівчат, одній дитині - 7,89\% дівчат. Бездітність вважають «ідеальним» варіантом $2,26 \%$ студенток. За умови необхідної якості життя двоє дітей у сім'ї хотіли б мати 70,40\% опитаних, одну і три дитини - 11,55\% і 12,27\% студенток відповідно. За вказаних умов 4,33\% дівчат не хотіли б взагалі мати дитину у сім'ї. Однак на момент опитування тільки 49,82\% дівчат хотіли б мати дві дитини, 5,05\% три, 19,86\% - одну дитину і 25,27\% - не планують мати дітей.

Вивчення репродуктивного поведінки і репродуктивних установок є важливим для розуміння і прогнозування тенденцій народжуваності у регіоні, для розробки конкретних заходів ефективної демографрічної і сімейної політики.

Ключові слова: репродуктивна поведінка, репродуктивні установки, репродуктивне здоров'я, дівчата.

УДК $613.96+314.172$

СОЦИАЛЬНО-ГИГИЕНИЧЕСКИЕ АСПЕКТЫ РЕПРОДУКТИВНОГО ПОВЕДЕНИЯ И РЕПРОДУКТИВНЫХ УСТАНОВОК ДЕВУШЕК 17-22 ЛЕТ

Калиниченко Д. О.

Резюме. В статье освещены и проанализированы особенности репродуктивного поведения женщин различных возрастных групп, определены факторы, его детерминирующих.

Целью работы было изучить репродуктивное поведение девушек 17-22 лет и репродуктивные установки для использования при разработке региональных программ демографической политики и проведения мониторинга демографической ситуации.

Исследованием было охвачено 284 студентки высших учебных заведений. Результаты анонимного анкетирования анализировались в двух возрастных группах 17-19 лет - I группа (145 человек) и 20-22 года - II группа (139 человек). Использовалась специально разработанная анкета для анонимного опроса, вопросы которой касались репродуктивных установок, уровня и источников информированности относительно полового воспитания, начала половой жизни, использования средств контрацепции, информированности о собственном ВИЧ-статусе.

Результаты исследования. По данным медицинских осмотров 76,92\% девушек признаны здоровыми, 23,08\% осмотренных имеют хронические заболевания репродуктивной системы. Дебют сексуальной активности приходится максимально на возрастной диапазон 17-18 лет (34,57\%) и 15-16 лет (19,15\%). У 5,53\% студенток половые связи сопровождались беременностью с последующим ее прерыванием. По данным опроса у $31,71 \%$ студенток, которые имели в анамнезе случайные половые связи, обнаружены болезни репродуктивной системы. Основным источником информации о репродуктивном поведении, 
репродуктивном здоровье в молодежной среде являются сверстники и друзья (48,40\%), медицинские интернет-ресурсы (45,74\%), беседы с родителями (32,45\%), СМИ и реклама $(28,72 \%)$, тематические занятия в учебных заведениях (17,02\%). В ходе исследования установлено, что 73,31\% респонденток считает два ребенка - идеальным количеством детей в семье, 16,17\% девушек отдают предпочтение трем детям в семье, одному ребенку - 7,89\% девушек. Бездетность считают «идеальным» вариантом 2,26\% студенток. При условии достаточного качества жизни, двое детей в семье хотели бы иметь 70,40\% опрошенных, одного ребенка и трех детей - 11,55\% и 12,27\% студенток соответственно. При существующих условиях 4,33\% девушек не хотели бы вообще иметь детей в семье. Однако на момент опроса только 49,82\% девушек хотели бы иметь двух детей, 5,05\% - трех, 19,86\% - одного ребенка и 25,27\% - не планируют иметь детей.

Изучение репродуктивного поведения и репродуктивных установок является важным фрактором для понимания и прогнозирования тенденций рождаемости в регионе, для разработки конкретных мероприятий эффективной демографической и семейной политики.

Ключевые слова: репродуктивное поведение, репродуктивные установки, репродуктивное здоровье, девушки.

The authors of this study confirm that the research and publication of the results were not associated with any conflicts regarding commercial or financial relations, relations with organizations and/or individuals who may have been related to the study, and interrelations of coauthors of the article.

Стаття надійшла 30.05.2019 p. Рекомендована до друку на засіданні редакційної колегії після рецензування 